\title{
АНТИКОРОЛІВСЬКЕ ПОВСТАННЯ У ТЛУМАЧЕННІ КОНСТИТУЦІЙНИХ РОЯЛІСТІВ 40-х рp. XVII ст.
}

\begin{abstract}
Анотація: У статті визначається поняття «конституційний роялізм», зазначаються ідейні витоки иієї теорії, розглядаються погляди прибічників даного політичного напрямку на спроби повстання проти влади монарха, розкривається місце короля у системі управління державою. Характеризуються погляди таких конституиійних роялістів, як Джон Спелмен і Джон Бремхол, на права й обов'язки короля та Парламенту. Крім того, зазначається, що відповідно до вчення вказаних мислителів, джерелом королівської влади є Бог, а населення не має права піднімати озброєне повстання проти свого правителя, оскільки він є помазаником божим навіть якщо він перетворюється на тирана.
\end{abstract}

Ключові слова: конституційний роялізм, «змішана монархія», Англійська революиія, недоторканість влади короля, походження держави

Ідея конституційного роялізму виникла напередодні Англійської революції і як явище в політичній думці Англії сформувалася у 1641-1642 pр. у відповідь на розвиток абсолютистських і парламентаристських концепцій управління країною. Теорія конституційного роялізму базується на уявленнях про те, що королівська влада не є абсолютною - вона обмежується за допомогою закону. Конституційні роялісти з їх традиційними і законними, на їхню думку, поглядами на інститути управління державою, наполягали на тому, що король повинен зберігати свої виконавчі функції, а інститут парламенту має виконувати функції дорадчого органу, допомагаючи правителю приймати нові закони й утверджувати нові види податків.

В англійській політичній думці середини XVII ст. не існувало поняття «конституційного роялізму». Цей термін вперше ввів англійський історик Девід Сміт для того, щоб охарактеризувати групу поміркованих роялістів, політичні погляди яких стали особливо помітними напередодні революції - у 1641- 1642 pp. ${ }^{1}$

Події 40-х - 60-х рр. XVII ст. в Англії привертають увагу істориків протягом століть. Не припиняються спроби пояснити, які були причини та наслідки однієї з найграндіозніших криз у британській історії. Незважаючи на те, що історія політичної думки Англії викликає жвавий інтерес серед дослідників, темі конституційного роялізму приділено дуже мало уваги. В основному досліджувалися політичні ідеї абсолютистів, а також їхніх опонентів - прибічників ідеї парламентаризму.

Історія політичної думки конституційних роялістів тільки починає досліджуватися, і це дозволяє прослідкувати процеси трансформації англійської політичної структури,

\footnotetext{
" Івченко Ольга Степанівна - Одеський національний університет імені I.I. Мечникова, Одеса, Україна. ORCID: https://orcid.org/0000-0003-0694-0004; e-mail: olga_ivchenko@ukr.net

${ }^{1}$ Smith D.L. Constitutional Royalism and the search for settlement, 1640-1649. Cambridge, 1994. P. 39.
} 
уявлень сучасників про владу та ії легітимність, розглянути широко відомі події під іншим кутом зору, уточнити та розширити наші знання у галузі політичної культури цієї переломної епохи. Це обумовлює актуальність даного дослідження.

У наукових роботах проводились дослідження ідей як абсолютистів, так і парламентаристів, порівнювались їхні політичні погляди. Однак при цьому практично не зверталась увага на існування групи представників ідеї конституційного роялізму.

У британській історіографії серед робіт, присвячених історії роялістської політичної думки Англії, необхідно відзначити дослідження Дж. Аллена, Дж. Самервілла, Р. Кроксдейла та Д. Сміта. По-перше, необхідно відзначити роботи історика Дж. Аллена ${ }^{2}$ Дослідник вважав, що всі прихильники королівської влади заперечували можливість повстання проти законного правителя, так як свою владу той отримав від Бога і тому може бути підзвітним тільки йому. Схожу оцінку ідеям роялістів давав і Дж. Самервілл‥ Його роботи - наступний етап дослідження ідей прихильників короля. Дж. Самервілл писав, що роялістські теорії про походження королівської влади мало чим відрізняються один від одного. Називаючи всіх роялістів прихильниками ідеї абсолютизму, Дж. Самервілл зазначав, що всі їх об’єднували дві ідеї: божественного походження влади правителя і положення про неприпустимість опору законному королю.

Дослідженням конституційної історії Англії займалися також Р. Кроксдейл ${ }^{4}$, який у своїй монографії проаналізував протистояння роялістів і парламентаристів напередодні Англійської революції, дослідивши основні теоретичні положення обох груп, однак при цьому зосереджувався в основному на ідеях представників абсолютизму, а представників теорії конституційного роялізму згадував дуже рідко.

На новий рівень вивчення роялістської політичної думки вийшло в працях англійського історика Девіда Сміта - автора низки робіт, найбільший інтерес серед яких представляє його дослідження «Constitutional Royalism and the Search for Settlement. 16401649» («Конституційний роялізм та пошук врегулювання. 1640-1649») ${ }^{5}$. У цій роботі Девід Сміт вводить поняття «конституційного роялізму» для позначення групи роялістів, що виступають з ідеєю «змішаної монархії» - обмеження влади правителя за допомогою законів. У своєму дослідженні автор детально проаналізував ті ідеї, з якими виступили представники цього напряму політичної думки, і які дозволяють об'єднати цих мислителів у єдину групу.

Радянська історіографія аналізувала Англійську революцію з позицій марксизму. Основні акценти досліджень були зміщені на аналіз соціально-економічних передумов громадянських воєн середини XVII ст. Особливої уваги заслуговують дослідження М.А. Барга ${ }^{6}$. Поряд із соціально-економічними проблемами він плідно розробляв теми політичної та релігійної історії, особливо ті, що пов'язані з передумовами, перебігом і наслідками буржуазних революцій XVI-XVIII ст. Учениця цього провідного історика

\footnotetext{
${ }^{2}$ Allen J.W. English political thought 1603-1660. London, 1938. Vol. 1.1603-1644. 340 p.

${ }^{3}$ Sommerville J.P. Politics and ideology in England 1603-1640. London, 1986. 485 p.

${ }^{4}$ Croxdale R. Constitutional theories of kingship during the English revolution 1637-1660. Texas, 1972. 148 p.

${ }^{5}$ Smith D.L. Op. cit.

${ }^{6}$ Барг М.А. Великая английская революция в портретах ее деятелей. Москва, 1991. 397 с.
} 
I.В. Нємченко ${ }^{7}$ вивчає ідеологічні аспекти Англійської революції, вона дослідила присутність ідей ренесансного гуманізму в політичній системі Томаса Гоббса, уявлення про державний суверенітет у роялістській політичній думці Англії 40-х років XVII ст. тощо.

Мета дослідження - з'ясувати погляди конституційних роялістів на повстання проти короля, вивчаючи трактати таких яскравих представників цього ідейного напрямку, як Джон Спелмен і Джон Бремхол.

Досягнення поставленої мети передбачає розв'язання наступних завдань:

- визначити основні положення конституційного роялізму як ідейної течії;

- порівняти погляди Джона Спелмена та Джона Бремхола на місце короля в управлінні державою.

Конституційні роялісти проголошували ідею «змішаної» монархії - правління короля у парламенті. Ідейні витоки цієї теорії можна виявити ще в XV ст. у політичних трактатах такого державного діяча, як Джон Фортеск'ю. Саме у його роботах ця ідея вперше отримала своє систематичне вираження. I ті положення, з якими виступали мислителі XVII ст. є, по суті, подальшою розробкою та доповненням ідей цього мислителя.

Для конституційних роялістів король був сувереном. Вони вважали, що все населення має визнати монарха верховним правителем у державі. Однак влада його не є абсолютною ${ }^{8}$ В Англії взагалі не існує абсолютної влади, проголошували роялісти. Повноваження короля обмежуються законом. При цьому сам монарх був джерелом закону і спочатку влада його була необмеженою - починаючи від Адама влада всіх перших правителів була абсолютною. Але в Англії королі з часом почали скликати лордів і представників общин, щоб порадитись 3 ними, і пообіцяли, що жодного закону не буде прийнято без їхньої на це згоди'.

Таким чином, король за власним бажанням обмежив свої повноваження та права й у зв'язку з цим монарх змушений був приймати закони разом 3 парламентом. При цьому самі палати також не мали права без згоди короля приймати або змінювати закони ${ }^{10}$. Крім того, конституційні роялісти підкреслювали недоторканість влади монарха. Ніхто не міг піднімати повстання проти правителя, адже він - помазаник Божий. Найяскравіше ці ідеї втілились у роботах Джона Спелмена та Джона Бремхола.

Джон Спелмен (1594-1643) був юристом і членом Парламенту у 1625 р., багато подорожував по континентальній Європі та був посвячений у лицарі в грудні 1641 р. I напередодні своєї смерті був призначений Карлом I на посаду державного секретаря ${ }^{11}$. Джон Спелмен - автор декількох політичних трактатів, в яких висловив свої погляди на походження влади короля, його функції та роль в управлінні державою. Одним з головних досліджень автора є трактат «Certain considerations upon the duties both of prince and people» («Деякі міркування щодо обов'язків короля та його підданих») - автор зазначає, що неможливість повстання проти короля пов'язана з походженням його влади та держави в цілому.

\footnotetext{
${ }^{7}$ Немченко И.В. Идея «смешанной монархии» в роялистской политической мысли Англии 40-х гг. XVII в. // Записки історичного факультету. Вип. 5. Одеса, 1997. С. 247-252.

${ }^{8}$ Allen J.W. Op. cit. P. 483.

${ }^{9}$ Ibid. P. 496.

${ }^{10}$ Ibidem.

${ }^{11}$ Smith D.L. Op. cit. P. 226.
} 
На підтвердження своєї думки Джон Спелмен наводить такі способи утворення королівства - природний, або цивільний, насильницький, чи військовий, і змішаний. Природний шлях - це «влада батька над дітьми, дітьми дітей та їх слугами». Мало того - «його влада виникла ще до того, як його піддані стали йому підпорядковуватись». Далі Спелмен зазначає, що влада монарха з самого початку була спадковою, «...передавалася по праву старшинства - від батька до старшого сина, правлінню якого підпорядковувалися за божим велінням молодші» ${ }^{12}$. А отже піддані в жодному випадку не мають права піднімати повстання проти свого правителя.

Другий спосіб створення королівства - насильницький - грунтується на тому, що одна людина підпорядковує інших людей, тобто, узурпатори та завойовники за допомогою меча поширюють свою владу. Король, за допомогою меча розширивши свої кордони, не підпорядковується жодним людським законам і править своїми підданими так, як вважає за потрібне. Таким чином, він перетворюється на тирана. Однак, навіть у цьому випадку автор заперечує можливість організації повстання проти короля. Єдине, що можуть зробити піддані - це не виконувати безбожні веління монарха.

Третій спосіб створення держави Джон Спелмен вважає найкращим. Мова йде про обмеження влади короля за допомогою законів. Піддані при «змішаному» виді управління державою підкорюються королю, влада якого «обмежена тими законами, на які населення дало свою згоду» ${ }^{13}$. Такі держави утворюються шляхом укладання договору між королем і підданими. Прибічники даної концепції стверджували, що населення країни тільки обирало особу правителя, а Бог наділяв обраного королівською владою ${ }^{14}$. І в цих випадках не можна ставити повноваження короля під сумнів, піднімати повстання проти монарха.

Слід зазначити, що при цьому і парламентаристи, і роялісти визнавали божественність влади короля, а також заявляли, що монархія - це найкраща форма правління. у 1628 р. лідери парламентської опозиції залишалися підданими короля. Аж до 1642 р. не йшла мова про можливість повстання проти монарха ${ }^{15}$.

Уявлення про те, що король отримав свою владу від Бога сягає своїм корінням ще раннього середньовіччя, коли тільки було утворено королівство в Англії. Теорія божественного права монарха була модифікацією дуже давньої ідеї, а саме, що влада має релігійне походження і схвалення. Жоден християнин не сумнівався в цьому. Для короля концепція божественної природи його влади була вигідна насамперед тим, що зверталась до безумовної покори йому всіх його підданих. 3 іншого боку, дана концепція ідеологічно обгрунтовувала незалежність короля від влади папи римського. У цьому своєму значенні божественна прерогатива королівської влади була корисною і 3 погляду англійського парламенту.

Про божественне походження королівської влади, про божественну монархію, про

\footnotetext{
${ }^{12}$ Spelman J. Certain considerations upon the duties both of prince and people Written by a gentleman of quality, a well-wisher both to the King and Parliament.URL: https://quod.lib.umich.edu/e/eebo/A61099.0001.001/1:2?rgn=div1;view=fulltext

${ }^{13}$ Spelman J. Certain considerations...

${ }^{14}$ Ibidem.

${ }^{15}$ Judson M.A. The Crisis of the Constitution. London, 1975. P. 19.
} 
короля як намісника Бога на землі часто говорилося на засіданнях англійського парламенту протягом XVI і першої половини XVII ст. Але за цими поняттями ховалася не думка про те, що король може керувати довільно, ніякими рамками себе не обмежуючи, а скоріше нагадування йому про його королівські обов'язки. Бог представлявся при цьому не у вигляді деякого вищого авторитету, що дозволяє королю робити все, що завгодно його величності і відповідно виправдує будь-які його дії, але як всемогутній творець і пан всесвіту, в який королю варто вірити й якому він повинен служити.

Спадкоємець Єлизавети I Тюдор на королівському престолі Яків I теж цілком усвідомлював те, що божественний характер королівської влади означає, що дії короля обмежені визначеними рамками. Розкриваючи парламентаріям своє розуміння королівської влади, він підкреслював, що «уся ця влада запропонована Богом Ad aedificationem, non ad destructionem (для творення, не для руйнування). Тому що, хоча Бог має як владу руйнування, так і творення, але не буде згідно з божественним розумом застосовувати свою владу в руйнуванні природи» ${ }^{16} .3$ цього Яків I робив висновок про те, що божевільним буде король, що буде винищувати своїх підданих чи заподіюватиме їм яке-небудь інше зло.

Джон Спелмен, як і решта конституційних роялістів, вважав, що король - втілення вищої влади держави, гарант її стабільності та добробуту. Стають очевидними наміри мислителя захищати права та привілеї короля. Автор більш повно розвиває ці положення у своєму останньому політичному трактаті - «The Case of our Affaires in Law, Religion, and other Circumstances briefly examined and presented to the conscience» («Вирішення наших справ у галузі права, релігії та інші обставини, коротко розглянуті і подані на усвідомлення»). Тут Джон Спелмен наголошував на тому, що «навіть наші закони визнають той факт, що... король був верховною владою, сувереном», чия корона була «найвищою короною, королівство його королівством, його державою, його володінням, народ його народом... Парламент у наших законах також зветься королівським парламентом» ${ }^{17}$. На думку мислителя, це підтверджує статус короля як верховного правителя і недоторканість його влади.

Джон Спелмен обгрунтовував свою думку про верховенство влади монарха, посилаючись на оформлення актів Парламенту: «...хоча серед нас є багато таких людей, яких ми називаємо лордами, проте жодного з них ми не вважаємо нашими лордами... а короля навіть Акти парламенту називають Нашим Лордом». Спелмен неодноразово зазначав, що тільки король володіє правом скликати Парламент як представницький орган, і за своїм бажанням король може розпустити його ${ }^{18}$. Верховна влада у королівстві втілюється в монархові, у законах, встановлених ним, і невіддільна від його особистості. Король, на думку автора, - це і верховний володар, і верховний суддя. Тому в таких справах, як забезпечення безпеки країни та захист її від зовнішніх ворогів, набір військ, придушення заколотів і повстань, скликання та розпуск Парламенту, вступ у війну та підписання мирних догово-

\footnotetext{
${ }^{16}$ James I. A Speech to the Lords and Commons of the Parliament at White-hall, on Wednesday the XXI. Of March. Anno 1609 [1610] // The Political Works of James I. URL: https://archive.org/details/politicalworksj00igoog

${ }^{17}$ Spelman J. The Case of our affaires in Law, Religion, and other circumstances briefly examined, and presented to the conscience. Oxford, 1643. P. 1.

${ }^{18}$ Ibidem.
} 
рів, всі повноваження зосереджується винятково в руках короля ${ }^{19}$. Тут мова йде про так звані надзвичайні права короля, або королівську прерогативу.

Джон Спелмен не сумнівався у тому, що верховна влада держави закріплена за особистістю короля. Король був верховним суддею та верховним законодавцем, він був «володарем, дії якого необмежені в тих питаннях, в яких не стримуються законом». Отже, «суверенність цієї держави» була ясно «втілена в королі... і нероздільно приєднана до його особистості» ${ }^{20}$.

Джон Спелмен доходить висновку, що у будь-якому випадку неправильно було б називати народ джерелом влади монарха. Король отримав свою владу тільки від Бога. Мислитель зазначав також, що «якщо король є верховною владою, в державі не існує жодної сили, чи влади, яка могла б законними шляхами змусити правителя відповісти за свої дії». Король повинен має правити в інтересах народу, але ніхто не може змусити його це робити. Саме Бог «був творцем і джерелом королівської влади», i «правителі були, по суті, підзвітні тільки йому одному» ${ }^{21}$. Оскільки правитель є помазаником Божим, то піддані не мають права позбавляти його влади, а тим більше - посягати на його життя.

Однак положення про те, що правитель є підзвітним тільки Богу, ще не означає, що його влада безмежна. Як і будь-хто інший, монарх повинен підкорюватись Божому закону, і в тому випадку, коли бажання або накази короля не будуть відповідати заповідям Бога, піддані мають право не коритися волі монарха. Але це не свідчить про те, що піддані можуть підняти озброєне повстання проти володаря. Вони повинні, у такому випадку, не виконувати наказів монарха, але повставати проти нього, а тим більше зазіхати на його життя, вони не мають права. Слід зазначити, що доктрина про неприпустимість виступу населення країни проти законного короля була найпопулярнішою в Англії у роки правління перших Стюартів ${ }^{22}$.

Будь-які виступи проти монарха, на думку Спелмена, є незаконними та суперечать християнському вченню - ті, хто виступають проти монарха, виступають проти Бога. Автор стверджував, що збройний виступ проти законного правителя, нехай навіть і тирана, ніколи не може бути виправданим ${ }^{23}$. I жоден закон не може таке повстання санкціонувати.

Мислитель вважав, що було б неправильно та незаконно «критикувати дії та методи правління короля, адже він - законний християнський монарх» ${ }^{24}$. При цьому автор знову посилається на приклади зі Святого Письма, зазначаючи, що: «Саул був королем, який погано правив королівством. Оскільки він був поганим правителем та відмовився від Бога, Давид за Божим велінням був помазаний на царство, але навіть після цього ніхто не став позбавляти Саула його корони, або намагатись вбити його. Навпаки, Саул став жорстоко переслідувати Давида, проте Бог віддав його в руки Давида, однак навіть тоді Давид не став вбивати Саула, хоча тільки так міг гарантувати свою безпеку. Він відрізав поділ від одягу Саула, і цим засвідчив свою відданість йому, бо замість цього міг позбавити його

\footnotetext{
${ }^{19}$ Ibid. P. 3.

${ }^{20}$ Ibid. P. 17.

${ }^{21}$ Spelman J. Certain considerations...

${ }^{22}$ Sommerville J.P. Politics and ideology in England 1603-1640. London, 1986. P. 35.

${ }^{23}$ Spelman J. Certain considerations...

${ }^{24}$ Ibidem.
} 
життя. Але Давид не став цього робити, бо це було 6 незаконно». Спелмен заявляв також, що було б помилкою вважати, ніби піддані можуть без короля управляти країною, вершити правосуддя і приймати рішення про те, що добре, а що погане. Населення країни не має такої влади, і якби піддані спробували 6 правити країною без монарха, це призвело $б$ до хаосу й анархії. Вирішувати всі ці питання має право тільки правитель ${ }^{26}$.

Джон Спелмен стверджував, що «відданість законам країни та верховній владі, яку втілює особа короля, забезпечує та зміцнює всі зв'язки обов'язку та послуху під загрозою покарання, багато прикладів якого ми знаходимо в Святому Письмі ${ }^{27}$. Тобто автор висловлював думку про те, що населення країни повинне дотримуватись законів держави та зберігати відданість монарху, як верховному правителю. У разі непослуху їх чекає страшна кара, схожа на ту, якою було «покарано народ Ізраїльський за те, що підняли повстання проти Мойсея, який за велінням Божим керував ними і був правителем їхнім... і загинуло багато синів та дочок Ізраїлевих ${ }^{28}$. Таким чином, мислитель вкотре підтверджував думку про неприпустимість озброєного повстання проти законного правителя, адже той поставлений Богом і піддані повинні коритися йому.

Схожі ідеї висловлював і Джон Бремхолл. Він був у колі англійських роялістів до липня 1644 р., поки не виїхав за кордон. Джон Бремхолл, архієпископ Арми і примас всієї Ірландії, народився близько 1593 р. У 1608 р. він почав навчання в Сідні Сассекс Колледж. Бремхолл отримав ступінь бакалавра мистецтв у 1612 p. і магістра у 1616 p. 24 грудня 1615 р. Бремхол був висвячений у сан диякона. У 1630 р. він став доктором богослов'я. Незабаром після цього мислитель був запрошений до Ірландії та прийняв це запрошення, хоча мав прекрасні перспективи кар'єрного зростання й у рідній країні.

Однак незабаром сміливі виступи Джона Бремхола на захист прав короля викликають незадоволення з боку представників аристократії і проти Бремхола розпочинається судовий процес. Тож йому доводиться таємно сідати на корабель, відпливати до Англії, де у цей час вже назрівало протистояння між прихильниками короля і Парламенту. Бремхолл не залишився осторонь цих подій: він оселився у Йоркширі і повністю присвятив себе справі захисту прав короля, написавши кілька трактатів, присвячених даній проблемі. Свою діяльність по захисту королівських прав Бремхолл продовжував до липня 1644 до битви при Марстон-Муре, у результаті якої вся північ країни опинився у руках парламенту. Після цього Бремхол таємно відплив до Гамбурга. I тільки в 1648 р. він повернувся до Ірландії .

Після Реставрації Стюартів єпископ Бремхол здійснює чергову подорож до Англії. Він був призначений архієпископом Арми і примасом всієї Ірландії. 31661 р. Джон Бремхол бере активну участь у діяльності Парламенту і якийсь час займає посаду спікера Па-

\footnotetext{
${ }^{25}$ Ibidem.

${ }^{26}$ Івченко О. Погляди Джона Спелмена на сутність королівської прерогативи // Записки історичного факультету. 2016. Вип. 27. С. 313-324.

${ }^{27}$ Spelman J. Certain considerations...

${ }^{28}$ Ibidem.

${ }^{29}$ Smith D.L. Op. cit. P. 338.

${ }^{30}$ The Works of the Most Reverend Father in God, John Bramhall; with a Life of the Author, and a Collection of His Letters: Life of Archbishop Bramhall. Sermons preached at the funeral of Archbishop Bramhall. URL: https:// https://archive.org/details/worksofmostrever00bram
} 
лати Лордів. У травні 1663 р. він повертається до Дубліна, але через кілька місяців Архієпископ Бремхолл вмирає $\epsilon^{31}$.

Джон Бремхолл був дуже послідовним проповідником і теологом. Його головною роботою є трактат The Serpent-Salve («Зміїний бальзам»). У своєму трактаті мислитель стверджує необхідність послуху «його Священній Величності». Автор задається питанням - «чого може чекати бідне королівство, якщо піддані не оберігають священного, а влаштовують хвилювання і заворушення?» ${ }^{32}$.

Автор вважає всі заяви про те, що «піддані, у яких немає права за допомогою меча брати на себе зобов'язання, після довгого періоду слухняності і слідування законам, після клятв вірності, можуть використовувати силу, щоб захистити свою природну свободу, або підняти зброю, щоб змінити встановлені закони» були «як брехливими, так і бунтівними». Бремхол зазначає, що не існує жодної причини, яка могла б виправдати збройне повстання - «навіть якщо суверен змушує своїх поданих вчиняти незаконні дії, ще більш незаконним буде повстання проти нього», адже «будь-яка влада, яка існує - від Бога... і ті, хто повстає проти влади - повстає проти Бога».

Автор заявляє, що закони Англії захищають країну від королівської тиранії: монархія - обмежена, а дії короля пов'язані його клятвою й існуванням різних структур, які охороняють благополуччя підданих. Але при цьому монарх володіє також різного роду надзвичайними правами - у разі непередбачених обставин, воєнних дій і т.д. «Король без особистої влади - це не король». Але тут автор знову нагадує, що «хороший король не стане порушувати закони королівства, але навіть ці закони не можуть виправдати збройне повстання проти поганого короля» ${ }^{33}$.

Джон Бремхол попереджає, що не варто ідеалізувати Парламент, хоча при цьому «сама назва Парламенту звучить музикою в наших вухах» ${ }^{34}$. Парламент, за Бремхолом, це частина королівства, за допомогою якої піддані беруть участь в управлінні країною. Втім це не гарантує їм верховенство над владою короля. Як і у решти конституційних роялістів, у Бремхолла присутня ідея «політичного тіла», де «король - це голова, а Парламент - тіло держави» ${ }^{35}$. Отже, заперечення збройного повстання проти Корони, концепція обмеження влади монарха за допомогою законів, повага до ролі Парламенту в «змішаному правлінні», необхідність збереження існуючої структури Англіканської церкви - всі ці ідеї Джона Бремхолла доводять, що його політичне вчення - одне з найбільш яскравих проявів конституційного роялізму в англійській політичної думки середини XVII ст.

Таким чином, ідея конституційного роялізму мала яскраво виражений компромісний характер, і її головною метою було примирення двох вороже налаштованих одна до одної теорій - абсолютизму та парламентаризму, що виникли у результаті протистояння короля та парламенту. Представники течії конституційного роялізму висловлювали низку схожих ідей стосовно системи управління державою, прав та обов'язків як короля, так і його підданих. Мова йде про такі положення:

\footnotetext{
${ }^{31}$ Ibidem.

${ }^{32}$ Bramhall J. The Serpent Slave. P. 352.

${ }^{33}$ Ibidem.

${ }^{34}$ Ibid. P. 318.

${ }^{35}$ Ibid. P. 363.
} 
- король є верховним володарем, правління якого обмежується за допомогою законiв;

- палати парламенту в жодному випадку не мають права посягати на королівську прерогативу і повинні допомагати монарху приймати нові закони або ж змінювати вже існуючі та вводити нові види податків;

- джерелом королівської влади є Бог, тому тільки перед ним правитель повинен відповідати за свої дії;

- скликання та розпуск парламенту залежить тільки від волі короля;

- населення не має права піднімати озброєне повстання проти свого правителя, оскільки він є помазаником божим і навіть якщо він перетворюється на тирана;

- тільки якщо повеління короля суперечать заповідям Божим, піддані можуть не підкоритись своєму правителю, але навіть в цьому випадку вони не мають права повстати проти нього, а тим більш, посягати на його життя.

Однак політичного об’єднання та створення окремої партії конституційним роялістам створити не вдалося. Цієї мети не ставили перед собою ні ті особи, що намагались втілити в життя основні положення конституційного роялізму, ні теоретики цієї концепції. Чому саме так трапилось і як розвивався конституційний роялізм після смерті короля - це перспективи для подальших досліджень.

Olga Ivchenko

\section{Anti-royal uprising in the interpretation of constitutional royalists of the 40-ies years of XVII century}

Abstract: The article is devoted to the study of the views of representatives of such a direction of English political thought of the XVII century as constitutional royalism. It is noted that the theory of constitutional royalism is based on the idea that royal power is not absolute - it is the reign of the king in Parliament. Constitutional royalists with traditional and legitimate views, in their view, on the institutions of government, insisted that the king retain his executive functions and the institution of parliament should act as an advisory body, helping the ruler pass new laws and pass new taxes.

The author uses the treatises of John Spelman and John Bremhol to study the views of representatives of constitutional royalism on the possibility of rebellion against the king's power. Thinkers converged on the idea that the king was the supreme ruler, whose rule was limited by law. The population has no right to raise an armed uprising against its ruler, because he is an anointed of God even if he becomes a tyrant.

Only when the king's commandments contradict God's commandments can the subjects disobey their ruler, but even then they have no right to rebel against him, much less encroach on his life. Any opposition to the monarch, according to Spelman and Bremhol, is illegal and contrary to Christian teaching - those who oppose the monarch oppose God. The authors argued that armed action against a legitimate ruler could never be justified. And no law can sanction such an uprising. 
For constitutional royalists, the king was a sovereign who voluntarily limited his will by obeying the law. They believed that the entire population should recognize the monarch as the supreme ruler of the state. In fact, the constitutional royalists professed the idea of a «mixed monarchy», which first appeared in the XV century. formulated by John Fortescue.

The main goal of the constitutional royalists was to reconcile two hostile theories - absolutism and parliamentarism, which arose as a result of the confrontation between the king and parliament. The development of this area of political thought in England in the XVII century during revolutionary events - prospects for further research.

Keywords: constitutional royalism, «mixed monarchy», the English Revolution, the inviolability of the king's power, the origin of the state 